\title{
A comparative study of fatty acids profile of two Indian major carps (Gibelion catla, Hamilton, 1822 and Cirrhinus mrigala, Hamilton, 1822) using value added fish feed
}

\author{
Avijit Kar* \\ Department of Zoology, Vidyasagar University, Midnapore-721102 (West Bengal), India \\ Deep Sankar Chini \\ Department of Zoology, Vidyasagar University, Midnapore-721102 (West Bengal), India \\ Manojit Bhattacharya \\ Department of Zoology, Vidyasagar University, Midnapore-721102 (West Bengal), India \\ Bidhan Chandra Patra \\ Department of Zoology, Vidyasagar University, Midnapore-721102 (West Bengal), India \\ Shampa Patra \\ 3 Sabang Sajani Kanta Mahavidyalaya, Lutunia, Paschim Medinipur-721166 (West Bengal), \\ India \\ Jayanta Kumar Saha \\ North Middlesex University Hospital, NHS Trust, London N181QX, UK \\ *Corresponding author. Email: avijitkarmsc@gmail.com
}

\section{How to Cite}

Kar, A. et al. (2021). A comparative study of fatty acids profile of two Indian major carps (Gibelion catla, Hamilton, 1822 and Cirrhinus mrigala, Hamilton, 1822) using value added fish feed. Journal of Applied and Natural Science, $13(2), 443$ - 449. https://doi.org/10.31018/jans.v13i2.2598

\begin{abstract}
Freshwater fishes are not only a major source of protein but they also possess nutritionally valuable lipids in the form of Polyunsaturated fatty acids (PUFAs), which play a crucial role in the normal growth, disease prevention, development, cardiovascular health and reproduction of human. The present study was performed to determine the incorporation rate of fatty acids profile and their composition in two common freshwater carps as Gibelion catla and Cirrhinus mrigala (in situ trial and experimental) in the different experimental time period ( 0 days, i.e. initial, 90 days and 180 days) by using of value added feed like flaxseed ( $\alpha-$ linolenic acids, $51.26 \%-54.94 \%$ ) and soybean oil ( $\alpha$-linolenic acids, $7.95 \%-9.01 \%$ ) as omega-3 supplements. To determine the specific growth pattern Length-Weight Relationships (LWRs) are analyzed where it showed positive allometric growth ( $b=3.20$ in 90 days, $b=3.11$ in 180 days for Catla and $b=3.18$ in 90 days, $b=3.1$ in 180 days for Mrigala fish). The Gas ChromatographyMass Spectrometry (GC/MS) method also confirmed that the percentages of EPA (eicosapentaenoic acid) and DHA (docosahexaenoic acid) increased significantly $(P<0.05)$ in experimental $(0.096 a \pm 0.41$, initial; 5.16a $\pm 0.27,90$ days; $6.21 \mathrm{~b} \pm 0.36$, 180 days Catla fish species and $0.019 \mathrm{a} \pm 0.96$ initial; $3.74 \mathrm{~b} \pm 0.37$, 90 days; $3.50 \mathrm{a} \pm 0.46180$ days for Mrigal fish species) fishes rather than controls $(4.28 \mathrm{a} \pm 0.27,90$ days; $4.36 \mathrm{~b} \pm 0.36,180$ days for Catla species and $2.24 \mathrm{~b} \pm 0.3190$ days; $2.50 \mathrm{a} \pm 0.11180$ days for Mrigal species). Therefore, it was clearly indicated that formulated diet performed significantly to maintain the positive allometric growth as well as successive enrichment of PUFAs in experimental specimens, which is beneficial for human health as high source of protein and PUFAs as well.
\end{abstract}

Keywords: Comparative study, Cirrhinus sp.,Fatty acids profile, Gibelion sp., Value added fish feed

\section{INTRODUCTION}

Freshwater farming fisheries sustained a positive growth over the years compared to marine fisheries supplying the basic nutritional needs for both developed and developing countries (Subasinghe et al.,2009) to satisfying livelihood demands for good quality of fish meal contain with reach sources of fat and animal protein. In addition to that, fisheries have supplied fresh fish meal and shellfish to global markets, and there is a collective opportunity for expanding value-added fish and fish by products ((Kaushik et al.,2004). However, a 
number of carp species, indigenous to the subcontinent, are available throughout India, which are the major protein sources and contain nutritionally valuable lipids and fatty acids (Mohanty et al.,2019). Further studies now comprise certain aspects on the enhancement of nutritional quality of some freshwater fishes under control and experimental feeding fishes in India. Although fish are considered as a rich animal source of polyunsaturated fatty acids (PUFAs), namely, Eicosapentacenoic acid (EPA; C20:5n3), Docosahexaenoic acid (DHA; C22:6n3), along with that, arachidonic acid (AA) and other PUFAs of the n-6 series, are precursor of biologically important food staffs, such as epoxides, AA-ethanolamide, considered to be the most beneficial in terms of human health (Galli and Marangoni 1997). Catla (Gibelion catla, Hamilton 1822) and Mrigal (Cirrhinus mrigala, Hamilton 1822), the most common two freshwater preferred carps among Indian consumers and cultured extensively across the Indian subcontinent (Misra and Samantaray 2004), mostly in culture ponds. The majority of Catla and Mrigal, marketed commercially as the product of fish farming, although a main capture fishery is active on the Ganga River and its tributaries (Dey et al.,2020) also contribute the bulk of fish farm production, with over 2.1 million tonnes (FAO 2018). Yet, the taste and nutritional quality of the fish meat, such as the fatty acid composition, varies with the seasonally and feeding of value added fish feeds (Ackman et al., 2002). The present study was an attempt to a comparative study of the fatty acid profiles between conventional control feeding and feeding by value added food supplements as flaxseeds in experimental cultured carps of the two major commercial carp like Catla and Mrigal species in India.

\section{MATERIALS AND METHODS}

\section{Experimental design and diets}

To complete the present research work, an experimental set-up comprised with 03 (Three) rectangular fibreglass aquarium where 3 control and 3 for experimental, 60 number of two Indian Major Carps (IMC) species like Gibelion catla (Hamilton, 1822) and Cirrhinus mrigala (Hamilton, 1822) fish species were taken (followed by the proper guideline and permission of the institutional ethical committee) for monoculture in each water tank (with same size and age), each measuring $100 \times 60 \times 50 \mathrm{~cm}$ with a provision for controlling temperature through thermostats, photoperiod for 180 days with automated system and water flow through a digital meter for a continuous flow. Water parameters like $\mathrm{pH}$, salinity, Dissolve Oxygen (DO), BOD are maintained in prescribed range for carp culture throughout the experimental period by using digital water parameter kit (Systronic 375).

The present evaluated the suitability of value added fish feed and to comparative analysis of incorporated fatty acids (feed developed by different fatty acids enrich ingredients, specifically flaxseed oil) with the comparison of normal diet related to fish feed. To the development of EPA and DHA in the trial/experimental species used flaxseeds as the main ingredients with the normal fish feed diet.

\section{Evaluation of growth parameters}

Length measurements were detailed as total length (TL in $\mathrm{cm}$ ) from the end part of the mouth to the end of the caudal fin measured to the nearest $0.1 \mathrm{~cm}$ by using a regular ruler validated against a Vernier calliper. Weight was measured using a digital balance with an accuracy of 0.01. Regression of the log transformed equation: $\log (W)=\log (a)+b \log (L)$, the parameters $a$ and $b$ were calculated with ' $a$ ' representing the intercept and ' $b$ ' the slope of the relationship. When $b$ is less than 3 , fish become slimmer with increasing length, and growth will be negatively allometric. When $b$ is greater than 3.0, fish become heavier, showing positive allometric growth and reflecting optimum conditions for growth. It should be noted that the stomachs of fish were not emptied before weighing. To investigate the LWRs data, ANOVA was used to evaluate the statistical significance of the regression model detected when $\mathrm{P}<0.05$. The coefficient of determination $\left(r^{2}\right)$ is a measure of the quality of a linear regression's prediction (a value close to 1 means a better model) (Chini, et al., 2019).

\section{Extraction of lipids and preparation of fatty acid methyl esters (FAME)}

Total lipid was extracted following the Folch et al. (1957) method. Evaporation of solvent was done under nitrogen stream and residues are weighed to quantify the amount of lipid extracted. The lipid residue was dissolved in chloroform/methanol $(2: 1, \mathrm{v} / \mathrm{v})$ and then stored in a $25 \mathrm{ml}$ conical flask with glass stopper under nitrogen at $-20^{\circ} \mathrm{C}$ until needed. The FAME's were prepared from the isolated lipids by the AOAC (1990) method.

\section{Gas chromatography}

GC/MS analysis of fatty acids profile derived from trial and control cultured sample specimen (Catla species and Mrigal species) were completed on a Shimadzu QP2010 quadrupole mass spectrometer with ionization $70 \mathrm{eV}$ energy operating in positive electronic where impact set within $100 \mu \mathrm{A}$, coupled with gas chromatography (Shimadzu GC 8060) equipped with a Carbowax (25 $\mathrm{m} \times 0.25 \mathrm{~mm}$; 0.25- $\mu \mathrm{m}$ film thickness) column with helium as the carrier gas.

\section{RESULTS AND DISCUSSION}

During the research period to the development of fatty acids level in trial fish specimen's muscle tissue, the 
Kar, A. et al. / J. Appl. \& Nat. Sci. 13(2), 443 - 449 (2021)

Table 1. Feed formulation of control diet and experimental diet (\% of dry matter; except moisture). This formulation was followed by feed formulation of ASA 32/6 of American Soybean Association International Marketing (FAO, 2003). This formulation is specifically dedicated for the IMC culture.

\begin{tabular}{llll}
\hline SI. No. & Dietary components & $\begin{array}{l}\text { Inclusion rate of } \\
\text { Control Diet (\%) }\end{array}$ & $\begin{array}{l}\text { Inclusion rate of } \\
\text { Experimental Diet (\%) }\end{array}$ \\
\hline 1. & Soybean meal, 47.5\% CP* & 52.00 \\
2. & Wheat flour, 11.7\% CP* & 30.20 & 28.20 \\
3. & Corn gluten meal, 60\% CP* & 6.50 & 6.50 \\
4. & Rice bran, 15\% CP* & 5.00 & 5.00 \\
5. & Crude flax seed oil & NA & 4.58 \\
6. & Crude soybean oil & NA & 1.40 \\
7. & Soy lecithin & 1.00 & 1.00 \\
8. & Vitamin premix & 0.75 & 0.75 \\
9. & Mineral premix & 0.50 & 0.50 \\
10. & Stay C 35\% & 0.04 & 0.04 \\
11. & Ethoxyquin 100\% & 0.03 & 0.03 \\
& Total & 100 & 100 \\
\hline
\end{tabular}

experimental diet mixed with normal feed ingredients as soybean meal, wheat flour, corn gluten meal, rice barn meal with crude flax seed was used. Flax seeds only used in experimental feed formulation as $4.58 \%$ in $100 \mathrm{gm}$ of formulated feeds (Table 1). After completion of 90 and 180 days of trial, the current research showed the positive allometric growth in both $G$. catla and C. mrigala in LWR pattern. The slope value (b) was calculated as 3.206 and 3.111 for 90 days and 180 days respectively for $G$. catla, as well as 3.183 and 3.104 calculated 90 days and 180 days respectively for C. mrigala (Table 2).

Although, to estimate the incorporation rate of fatty acids profile in two carp's species showed that deposition was remarkably increased day by day regular feeding of formulated feed staff rather than the normal feeds. The results also clearly indicated that mono saturated fatty acids (MUFA) increased in experimental Catla fish species' muscle $9.65 \%$ to $35.77 \%$ for the initial stage to first 90days culture period and $35.77 \%$ to $38.93 \%$ for the next 180 days of culture. Whether, in Mrigala fish species muscle showed MUFA developed $9.48 \%$ in the initial stage to $32.25 \%$ for 90days culture and $38.93 \%$ in final stage at 180days cultured period. However, feeding with conventional fish feed did not show such development of fatty acids profile in control culture of Catla and Mrigal fish species muscle. Accordingly, PUFAs like Linoleic Acid (C18:2n6), a- Linolenic Acid (C18:3n3), Eicosapentacenoic acid (EPA; C20:5n3), Docosahexaenoic acid (DHA; C22:6n3) and others were also well developed in experimental species rather than the control cultured species (Table 3 and 4 ).

The present investigation carried out the comparison of incorporation rates of fatty acids profile by conventional feeding and formulated feeding during the cul- ture of 180 days experiments. Although, in carp culture, variations in the fatty acid composition might be related to changes in the nutritional habits of the fish (Guler et al.,2008) and fat content was influenced by species, season, geographical regions, age and maturity (Osman et al.,2001) (Dalbir et al. 2015). In the present study, variations in MUFA and PUFA content in the two carps might be attributed to the reason of their feeding habits as conventional and formulated (Roques, et al., 2020). Our analyses of the proximate composition of cultured with conventional feed and value added fish feed revealed that value added feed cultured fish contained significantly higher lipid levels and a lower moisture content than its control feeding. It was found that Flaxseed (Linum usitatissimum) was one of the most important oilseed crops for industrial as well for food and feed purposes because of its exceptionally high content of a-linolenic acid (ALA, $18: 3 n-3)$ and lignans and considered traditional source of dietary omega-3 fatty acids while flaxseed oil could be used as a vegetarian source of dietary omega-3 fatty acids (Singh et al.,2011). Thus, current research dealt with flax seeds as a value added supplements to enhance the fatty acids level in cultured fish muscle. However, without value added control feeding cultured fishes, there was no found such development of poly unsaturated fatty acids in fish muscle tissue. In addition to that, the EPA and DHA incorporation level was significantly increased with $4.28 \%$ to $5.16 \%$ in Catla fish species and $2.24 \%$ to $3.74 \%$ in Mrigal during 90 days of cultured periods by the value added feeding. The results also explained that the development rate of fatty acids was higher in 90days of culture than next 180days (Fig. 1a and 1b). However, the most imperative finding of the present study was the distinct variance between controlled and experi- 
Table 2. Length-Weight relation of total cultured species of fishes.

\begin{tabular}{|c|c|c|c|c|c|c|c|c|c|}
\hline \multirow[t]{2}{*}{ Scientific name } & \multirow{2}{*}{$\begin{array}{l}\text { Culture } \\
\text { period }\end{array}$} & \multirow{2}{*}{$\begin{array}{l}\text { No. of } \\
\text { sample } \\
\text { (n) }\end{array}$} & \multicolumn{2}{|c|}{$\begin{array}{l}\text { Length (L) } \\
(\mathbf{c m})\end{array}$} & \multicolumn{2}{|c|}{$\begin{array}{l}\text { Weight (W) } \\
\text { (gm) }\end{array}$} & \multicolumn{3}{|c|}{$\begin{array}{c}\text { Length Weight Relationship } \\
\text { (LWR) }\end{array}$} \\
\hline & & & Max & Min & Max & Min & b & $a$ & $r^{2}$ \\
\hline \multirow{2}{*}{$\begin{array}{l}\text { Gibelion catla } \\
\text { (Hamilton, 1822) }\end{array}$} & 90 & 40 & 28.1 & 24.4 & 436.80 & 280.23 & 3.206 & 0.0095 & 0.945 \\
\hline & 180 & 30 & 33.8 & 31.3 & 649.94 & 537.01 & 3.111 & 0.0114 & 0.93 \\
\hline \multirow{2}{*}{$\begin{array}{l}\text { Cirrhinus mriga- } \\
\text { la (Hamilton, } \\
\text { 1822) }\end{array}$} & 90 & 40 & 31.9 & 28.0 & 388.76 & 253.44 & 3.183 & 0.0060 & 0.954 \\
\hline & 180 & 30 & 37.8 & 35.2 & 599.01 & 500.05 & 3.104 & 0.0076 & 0.936 \\
\hline
\end{tabular}

Table 3. Fatty acids deposition rate of Catla and Mrigala fish during 90 days culture period.

\begin{tabular}{|c|c|c|c|c|c|c|}
\hline \multirow[t]{3}{*}{ Fatty Acids } & \multicolumn{2}{|c|}{ Initial } & \multicolumn{4}{|c|}{90 days } \\
\hline & \multirow[t]{2}{*}{ G. catla } & \multirow[t]{2}{*}{ C. mrigala } & \multicolumn{2}{|c|}{ G. catla } & \multicolumn{2}{|c|}{ C. mrigala } \\
\hline & & & Control & Experiment & Control & Experiment \\
\hline Myristic acid $\left(\mathrm{C}_{14: 0}\right)$ & $3.49^{\mathrm{a}} \pm 0.23$ & $4.60^{\mathrm{a}} \pm 0.42$ & $7.48^{b} \pm 0.20$ & $6.13^{\mathrm{b}} \pm 0.11$ & $5.69^{b} \pm 0.32$ & $4.71^{\mathrm{b}} \pm 0.23$ \\
\hline Pentadecanoic acid $\left(\mathrm{C}_{15: 0}\right)$ & ND & $3.72^{\mathrm{a}} \pm 0.09$ & $2.25^{\mathrm{b}} \pm 0.09$ & $2.15^{\mathrm{b}} \pm 0.06$ & $2.10^{\mathrm{a}} \pm 0.13$ & $2.11^{\mathrm{a}} \pm 0.03$ \\
\hline Palmitic acid $\left(\mathrm{C}_{16: 0}\right)$ & $30.18^{c} \pm 0.51$ & $12.84^{\mathrm{b}} \pm 0.69$ & ND & $1.61 \pm 0.03$ & $31.28^{c} \pm 0.61$ & $33.28^{\mathrm{C}} \pm 0.52$ \\
\hline Heptadecanoic acid $\left(\mathrm{C}_{17: 0}\right)$ & ND & ND & $3.80 \pm 0.12$ & $2.35 \pm 0.02$ & $1.89 \pm 0.04$ & $1.09 \pm 0.05$ \\
\hline Stearic acid $\left(\mathrm{C}_{18: 0}\right)$ & $12.41^{\mathrm{b}} \pm 0.18$ & ND & $17.02^{\mathrm{C}} \pm 0.18$ & $15.02^{\mathrm{C}} \pm 0.07$ & ND & $0.03 \pm 0.13$ \\
\hline Arachidic acid $\left(\mathrm{C}_{20: 0}\right)$ & ND & $0.12^{\mathrm{a}} \pm 0.01$ & ND & $0.03 \pm 0.01$ & $0.45^{\mathrm{a}} \pm 0.13$ & $0.46^{\mathrm{a}} \pm 0.07$ \\
\hline Heneicosanoic acid $\left(\mathrm{C}_{21: 0}\right)$ & $1.55^{\mathrm{a}} \pm 0.19$ & $4.73^{\mathrm{b}} \pm 0.28$ & $8.31^{b} \pm 0.07$ & $8.01^{\mathrm{b}} \pm 0.005$ & $3.21^{\mathrm{a}} \pm 0.03$ & $3.62^{\mathrm{a}} \pm 0.12$ \\
\hline Tricosanoic acid $\left(\mathrm{C}_{23: 0}\right)$ & ND & ND & ND & ND & $1.16^{\mathrm{c}} \pm 0.01$ & $1.06^{c} \pm 0.03$ \\
\hline Others & $1.62 \pm 0.31$ & $1.02 \pm 0.17$ & $2.73 \pm 0.40$ & $2.61 \pm 0.33$ & $1.49 \pm 0.07$ & $1.89 \pm 0.01$ \\
\hline$\Sigma$ SFA & $49.18^{d} \pm 1.56$ & $27.31^{\mathrm{a}} \pm 1.65$ & $41.56^{\mathrm{c}} \pm 0.04$ & $39.17 \pm 0.02$ & $48.93^{b} \pm 0.34$ & $52.95^{\mathrm{b}} \pm 0.06$ \\
\hline Pentadecenoic acid $\left(\mathrm{C}_{15: 1}\right)$ & ND & ND & ND & $0.07^{\mathrm{a}} \pm 0.02$ & ND & $0.07 \pm 0.19$ \\
\hline Palmitoleic acid $\left(\mathrm{C}_{16: 1 \mathrm{n} 7}\right)$ & $1.48^{\mathrm{a}} \pm 0.17$ & $2.48^{\mathrm{a}} \pm 0.17$ & $0.18^{\mathrm{a}} \pm 0.02$ & $1.21^{\mathrm{a}} \pm 0.07$ & $23.89^{b} \pm 0.25$ & $34.09^{b} \pm 0.05$ \\
\hline Oleic Acid $\left(\mathrm{C}_{18: 1 \mathrm{n} 9}\right)$ & $6.15^{\mathrm{b}} \pm 0.73$ & $4.13^{\mathrm{C}} \pm 0.56$ & $0.68^{\mathrm{a}} \pm 0.05$ & $0.38^{\mathrm{a}} \pm 0.02$ & $5.42^{\mathrm{b}} \pm 0.99$ & $6.76^{\mathrm{b}} \pm 0.09$ \\
\hline Eicosenoic acid $\left(\mathrm{C}_{20: 1 \mathrm{n} 9}\right)$ & ND & $2.74^{\mathrm{b}} \pm 0.55$ & $28.24^{a} \pm 0.40$ & $30.04^{a} \pm 0.85$ & $3.49 b \pm 0.49$ & $3.98 b \pm 0.39$ \\
\hline Erucic acid $\left(\mathrm{C}_{22: 1 n 9}\right)$ & ND & $1.89^{b} \pm 0.15$ & ND & $0.003 \pm 0.01$ & $3.60^{\mathrm{C}} \pm 0.14$ & $4.05 \pm 0.12$ \\
\hline Others & $0.90 \pm 0.08$ & $0.73 \pm 0.06$ & $3.17 \pm 0.18$ & $3.07 \pm 0.15$ & $0.48 \pm 0.10$ & $0.28 \pm 0.17$ \\
\hline$\Sigma$ MUFA & $09.65^{\mathrm{b}} \pm 1.01$ & $09.48^{\mathrm{d}} \pm 1.21$ & $32.25^{a} \pm 0.45$ & $35.77^{\mathrm{a}} \pm 0.45$ & $37.87^{c} \pm 0.21$ & $38.93^{\mathrm{C}} \pm 0.15$ \\
\hline Linoleic Acid $\left(\mathrm{C}_{18: 2 n 6}\right)$ & $0.34 \pm 0.17$ & $0.974^{\mathrm{c}} \pm 1.27$ & $8.99^{b} \pm 0.64$ & $10.09^{b} \pm 0.61$ & ND & $0.84 \pm 0.07$ \\
\hline$\alpha$ - Linolenic Acid $\left(\mathrm{C}_{18: 3 n 3}\right)$ & $7.02^{\mathrm{a}} \pm 0.11$ & $4.34 \pm 0.17$ & $5.53^{\mathrm{b}} \pm 0.94$ & $6.13^{\mathrm{b}} \pm 0.85$ & $3.47 \pm 0.57$ & $4.17 \pm 0.73$ \\
\hline Arachidonic acid $\left(\mathrm{C}_{20: 4 n 6}\right)$ & ND & $0.28^{\mathrm{a}} \pm 0.13$ & ND & ND & $0.31^{\mathrm{a}} \pm 0.01$ & $1.25^{\mathrm{a}} \pm 0.05$ \\
\hline Eicosatrienoic acid $\left(\mathrm{C}_{20: 3 n 6}\right)$ & ND & ND & ND & ND & ND & $0.13 \pm 0.03$ \\
\hline $\begin{array}{l}\text { Eicosapentaenoic acid } \\
\left(\mathrm{C}_{20: 5 \mathrm{n} 3}\right)\end{array}$ & $0.008^{a} \pm 0.11$ & $0.019^{a} \pm 0.96$ & $3.78^{\mathrm{a}} \pm 0.24$ & $4.08^{\mathrm{a}} \pm 0.41$ & $1.92^{\mathrm{a}} \pm 0.07$ & $2.02^{\mathrm{a}} \pm 0.11$ \\
\hline $\begin{array}{l}\text { Docosahexaenoic acid } \\
\left(\mathrm{C}_{22: 6 n 3}\right)\end{array}$ & $0.078^{\mathrm{a}} \pm 0.30$ & ND & $0.50^{\mathrm{a}} \pm 0.03$ & $0.98^{\mathrm{a}} \pm 0.32$ & $0.32 \pm 0.3$ & $1.72 \pm 0.05$ \\
\hline Others & $0.97 \pm 0.43$ & $1.23 \pm 0.61$ & $2.86 \pm 0.35$ & $2.86 \pm 0.51$ & $1.80 \pm 0.14$ & $1.18 \pm 0.19$ \\
\hline$\Sigma$ PUFA & $09.23^{a} \pm 0.60$ & $06.74^{\mathrm{b}} \pm 2.89$ & $19.36^{b} \pm 0.75$ & $23.54^{\mathrm{b}} \pm 0.75$ & $10.21^{\mathrm{a}} \pm 0.55$ & $11.91^{\mathrm{a}} \pm 0.47$ \\
\hline$\Sigma \omega-3$ PUFA & $10.01^{\mathrm{a}} \pm 0.49$ & $5.16^{\mathrm{a}} \pm 1.05$ & $13.89^{b} \pm 0.87$ & $14.09^{b} \pm 0.63$ & $7.41^{\mathrm{a}} \pm 0.74$ & $8.41^{\mathrm{a}} \pm 0.33$ \\
\hline$\Sigma \omega-6$ PUFA & $1.24^{\mathrm{a}} \pm 0.47$ & $19.62^{b} \pm 2.08$ & $13.74^{d} \pm 1.34$ & $14.06^{d} \pm 0.57$ & $2.41^{\mathrm{a}} \pm 0.34$ & $2.84^{\mathrm{a}} \pm 0.41$ \\
\hline$\omega-3: \omega-6$ PUFA & $9.24 \pm 3.11$ & $0.26^{a} \pm 0.03$ & $1.0 \pm .02$ & $1.56 \pm 0.02$ & $3.10^{b} \pm 0.13$ & $3.49^{b} \pm 0.03$ \\
\hline$E P A+D H A$ & $0.096^{a} \pm 0.41$ & $0.019^{a} \pm 0.96$ & $4.28^{\mathrm{a}} \pm 0.27$ & $5.16^{\mathrm{a}} \pm 0.27$ & $2.24^{\mathrm{b}} \pm 0.31$ & $3.74^{\mathrm{b}} \pm 0.37$ \\
\hline
\end{tabular}

mental cultured fish species in terms of fatty acids level in the muscle tissue: experimental fishes had higher levels of PUFAs comparatively than control feeding. Ackman et al. (2002) stated that incorporation of polar lipid levels reached $10.6 \%$ in Indian major carps feed- ing with value added natural food, while Sharma et al. (2010) reported $8.51 \%$ in Mrigal and $14 \%$ in Catla carp species.

Although a general trend towards improvement of standard living worldwide, human beings were attract- 
Kar, A. et al. / J. Appl. \& Nat. Sci. 13(2), 443 - 449 (2021)

Table 4. Fatty acids deposition rate of Catla and Mrigala fish during 180 days culture period.

\begin{tabular}{|c|c|c|c|c|}
\hline \multirow{3}{*}{ Fatty Acids } & \multicolumn{4}{|c|}{180 days } \\
\hline & \multicolumn{2}{|c|}{ G. catla } & \multicolumn{2}{|c|}{ C. mrigala } \\
\hline & Control & Experiment & Control & Experiment \\
\hline Myristic acid $\left(\mathrm{C}_{14: 0}\right)$ & ND & ND & ND & $0.51^{\mathrm{D}} \pm 0.08$ \\
\hline Pentadecanoic acid $\left(\mathrm{C}_{15: 0}\right)$ & $0.01^{\mathrm{a}} \pm 0.02$ & $0.31^{\mathrm{a}} \pm 0.01$ & $6.44^{b} \pm 0.10$ & $7.19^{b} \pm 0.005$ \\
\hline Palmitic acid $\left(\mathrm{C}_{16: 0}\right)$ & $0.04^{\mathrm{a}} \pm 0.02$ & $0.09^{\mathrm{a}} \pm 0.06$ & $5.18^{\mathrm{a}} \pm 0.07$ & $7.08^{\mathrm{a}} \pm 0.32$ \\
\hline Heptadecanoic acid $\left(\mathrm{C}_{17: 0}\right)$ & ND & $0.09 \pm 0.05$ & $0.75^{\mathrm{b}} \pm 0.03$ & $0.95^{\mathrm{b}} \pm 0.07$ \\
\hline Stearic acid $\left(\mathrm{C}_{18: 0}\right)$ & $14.16^{b} \pm 0.50$ & $15.06^{\mathrm{b}} \pm 0.16$ & $3.37 \pm 0.38$ & $4.07 \pm 0.81$ \\
\hline Arachidic acid $\left(\mathrm{C}_{20: 0}\right)$ & ND & $0.99^{\mathrm{a}} \pm 0.05$ & $5.70^{c} \pm 0.03$ & $7.35^{\mathrm{c}} \pm 0.11$ \\
\hline Heneicosanoic acid $\left(\mathrm{C}_{21: 0}\right)$ & $0.99^{\mathrm{a}} \pm 0.05$ & $1.02^{\mathrm{a}} \pm 0.01$ & ND & $0.41^{\mathrm{b}} \pm 0.17$ \\
\hline Tricosanoic acid $\left(\mathrm{C}_{23: 0}\right)$ & ND & ND & $0.60^{\mathrm{b}} \pm 0.08$ & $0.54^{\mathrm{b}} \pm 0.14$ \\
\hline Others & $5.31 \pm 0.40$ & $4.91 \pm 0.70$ & $1.25 \pm 0.02$ & $2.05 \pm 0.12$ \\
\hline$\Sigma$ SFA & $20.84^{a} \pm 0.43$ & $20.84^{a} \pm 0.59$ & $28.35^{\mathrm{a}} \pm 0.75$ & $30.15^{\mathrm{a}} \pm 0.48$ \\
\hline Pentadecenoic acid $\left(\mathrm{C}_{15: 1}\right)$ & ND & $0.32^{\mathrm{a}} \pm 0.03$ & ND & $0.95^{\mathrm{C}} \pm 0.10$ \\
\hline Palmitoleic acid $\left(\mathrm{C}_{16: 1 \mathrm{n} 7}\right)$ & $2.62^{\mathrm{b}} \pm 0.21$ & $3.82^{b} \pm 0.11$ & $24.75^{\mathrm{C}} \pm 0.20$ & $35.95^{C} \pm 0.10$ \\
\hline Oleic Acid $\left(\mathrm{C}_{18: 1 \mathrm{n} 9}\right)$ & $38.84^{c} \pm 0.15$ & $39.54^{c} \pm 0.58$ & $7.08^{\mathrm{a}} \pm 0.84$ & $8.37^{\mathrm{a}} \pm 0.04$ \\
\hline Eicosenoic acid $\left(\mathrm{C}_{20: 1 \mathrm{n} 9}\right)$ & ND & ND & $0.07^{\mathrm{a}} \pm 0.04$ & $1.03^{\mathrm{a}} \pm 0.01$ \\
\hline Erucic acid $\left(\mathrm{C}_{22: 1 \mathrm{n} 9}\right)$ & ND & $0.007 \pm 0.03$ & $0.009^{\mathrm{a}} \pm 0.005$ & $0.007^{\mathrm{a}} \pm 0.002$ \\
\hline Others & $1.04 \pm 0.14$ & $1.47 \pm 0.04$ & $2.07 \pm 0.64$ & $3.01 \pm 0.07$ \\
\hline$\Sigma$ MUFA & $46.01^{\mathrm{C}} \pm 0.41$ & $48.22^{\mathrm{C}} \pm 0.52$ & $26.01^{\mathrm{b}} \pm 1.00$ & $27.21^{\mathrm{b}} \pm 1.00$ \\
\hline Linoleic Acid $\left(\mathrm{C}_{18: 2 n 6}\right)$ & $5.52^{\mathrm{b}} \pm 0.12$ & $6.02^{b} \pm 0.02$ & $09.55 \pm 0.04$ & $09.55 \pm 0.04$ \\
\hline$\alpha$ - Linolenic Acid $\left(\mathrm{C}_{18: 3 \mathrm{n} 3}\right)$ & $10.84^{\mathrm{c}} \pm 0.06$ & $13.14^{\mathrm{C}} \pm 0.07$ & $2.34 \pm 0.67$ & $2.34 \pm 0.67$ \\
\hline Arachidonic acid $\left(\mathrm{C}_{20: 4 n 6}\right)$ & ND & ND & $15.08^{\mathrm{b}} \pm 0.51$ & $15.08^{\mathrm{b}} \pm 0.51$ \\
\hline Eicosatrienoic acid $\left(\mathrm{C}_{20: 3 n 6}\right)$ & ND & $1.02 \pm 0.04$ & ND & $1.13^{a} \pm 0.01$ \\
\hline Eicosapentaenoic acid $\left(\mathrm{C}_{20: 5 n 3}\right)$ & $3.14^{b} \pm 0.18$ & $4.14^{\mathrm{b}} \pm 0.11$ & $1.18^{\mathrm{a}} \pm 0.10$ & $1.98^{\mathrm{a}} \pm 0.16$ \\
\hline Docosahexaenoic acid $\left(\mathrm{C}_{22: 6 n 3}\right)$ & $1.02 \pm 0.14$ & $2.07 \pm 0.15$ & $1.32 \pm 0.25$ & $2.52 \pm 0.31$ \\
\hline Others & $2.54 \pm 0.44$ & $2.59 \pm 0 . .14$ & $6.01 \pm 0.62$ & $5.91 \pm 0.71$ \\
\hline$\Sigma$ PUFA & $31.74^{\mathrm{b}} \pm 0.07$ & $32.98^{\mathrm{b}} \pm 0.31$ & $35.15^{\mathrm{c}} \pm 0.75$ & $38.41^{\mathrm{c}} \pm 1.06$ \\
\hline$\Sigma \omega-3$ PUFA & $15.09^{c} \pm 0.08$ & $20.09^{c} \pm 0.44$ & $5.02^{a} \pm 0.87$ & $7.02^{\mathrm{a}} \pm 0.09$ \\
\hline$\Sigma \omega-6$ PUFA & $4.18^{c} \pm 0.46$ & $7.11^{\mathrm{c}} \pm 0.51$ & $28.14 \pm 1.11$ & $30.14 \pm 1.13$ \\
\hline$\omega-3: \omega-6$ PUFA & $1.12 \pm 0.07$ & $2.17 \pm 0.32$ & $0.20^{\mathrm{a}} \pm 0.02$ & $0.40^{a} \pm 0.05$ \\
\hline EPA+DHA & $4.16^{b} \pm 0.36$ & $6.21^{b} \pm 0.36$ & $2.50^{\mathrm{a}} \pm 0.11$ & $3.50^{\mathrm{a}} \pm 0.46$ \\
\hline
\end{tabular}

ing more and more health conscious, preferring to ingest nutritious food added with some health benefits. Fish enrichment in PUFAs had numerous health benefits, as PUFAs played a vital role in mitigating antiatherosclerotic, cardioprotective, antithrombotic, and anti-arrhythmic disease, along with the improvement of normal eye and brain development in the human body (Jakhar et al.,2012). However, based on our current study results, the variation in the fatty acid profiles of value added feeding culture catla and mrigal fish species might be attributed primarily to the dietary intake of the fish rather than controlled feeding species.

\section{Conclusion}

The present investigation showed that dietary feed supplements regulated and enhanced the incorporation rate of PUFAs in the two common IMCs (Catla and Mrigal). Using flaxseeds as a value added fish feed diet confirms better growth performance and efficiency of feed utilization. Thus, the nutritional value of cultured species can be improved by integrating desired fatty acids, such as linoleic acid, linolenic acid, EPA, and $\mathrm{DHA}$, into the value added feed. A well-designed comparative present research work of lipid and fatty acids 


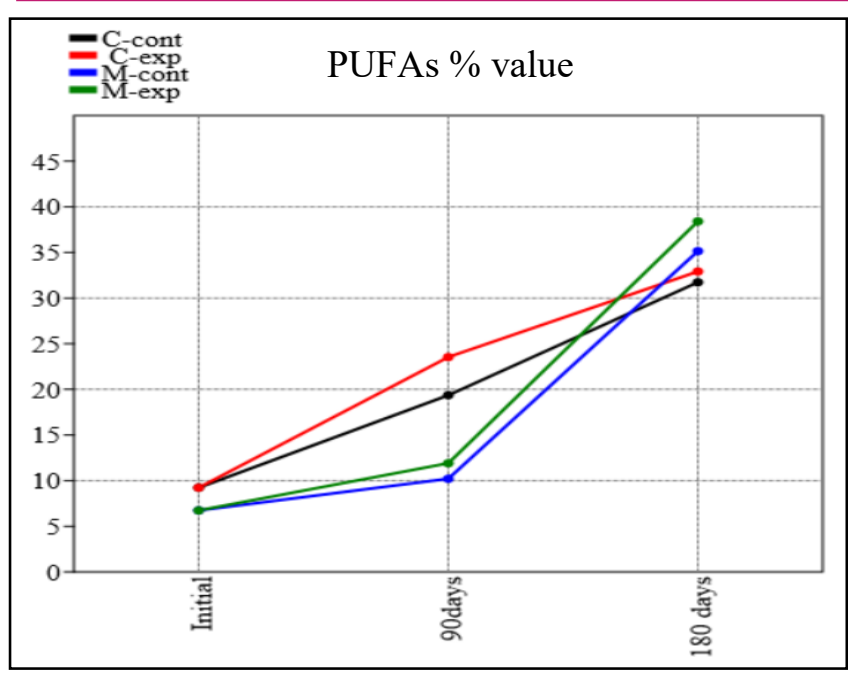

Fig.1a. Comparative analysis of PUFAs in Catla and Mrigala fish muscle content during control and experimental culture period.

of the two carp species of fish needs to be carried out in the future diet formulation.

\section{Conflict of interest}

The authors declare that they have no conflict of interest.

\section{REFERENCES}

1. Ackman, R.G., McLeod, C., Misra, K.K. \& Rakshit, S. (2002). Lipids and fatty acids of five freshwater food fishes of India. Journal of Food Lipids, $\quad 9(2), \quad 127-145$ doi: 10.1111/j.17454522.2002.tb00214.x

2. Chini, D.S., Bhattacharya, M., Kar, A., Malick, R.C., Patra, B.C., Patra, S. \& Das, B.K. (2019). Lengthweight relationships of three freshwater fish species from Rupnaryan and Kangsabati River, West Bengal, India. Journal of Applied Ichthyology, 35(2), 585 -586 doi: 10.1111/jai.13823

3. Dalbir, S. P., Roopma, G., Ritu, K., Vaini, G., \& Shivalika, R. (2015). Effect of fish oil substitution with sunflower oil in diet of juvenile Catla catla (Ham) on growth performance and feed utilization. Journal of Fisheries \& Livestock Production, 1-3. doi:10.4172/2332-2608.1000144

4. Dey, S., Choudhary, S.K., Dey, S., Deshpande, K. \& Kelkar, N. (2020). Identifying potential causes of fish declines through local ecological knowledge of fishers in the Ganga River, eastern Bihar, India. Fisheries Management and Ecology, 27(2), 140-154. doi: 10.1111/fme. 12390

5. FAO (2018). Aquaculture production. Year book of fishery statistics, vol 96. Food and Agriculture Organization of the United Nations, Rome, Italy.

6. Folch, J., Lees, M. \& Stanley, G.S. (1957). A simple

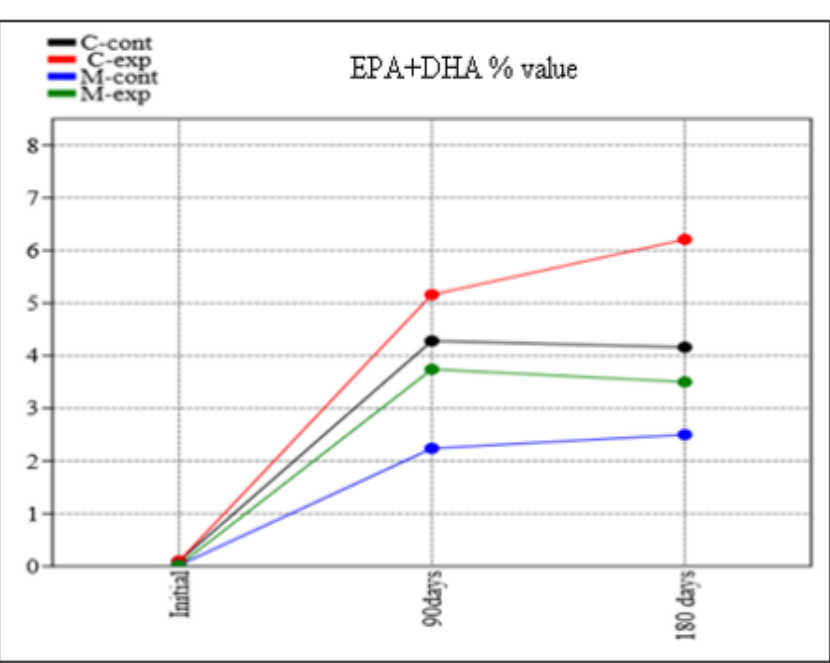

Fig.1b. Comparative analysis of EPA and DHA in Catla and Mrigala fish muscle content during control and experimental culture period.

method for the isolation and purification of total lipides from animal tissues. Journal of Biological Chemistry, 226(1), 497-509.

7. Galli, C. \& Marangoni, F. (1997). Recent advances in the biology of $n-6$ fatty acids. Nutrition, 13(11-12), 978-985. doi:10.1016/S0899-9007(97)00341-9

8. Guler, G.O., Kiztanir, B., Aktumsek, A., Citil, O.B. \& Ozparlak, H. (2008). Determination of the seasonal changes on total fatty acid composition and $\omega 3 / \omega 6$ ratios of carp (Cyprinus carpio L.) muscle lipids in Beysehir Lake (Turkey). Food Chemistry, 108(2), 689-694. doi: 10.1016/j.foodchem.2007.10.080

9. Jakhar, J.K., Pal, A.K., Reddy, D.A., Sahu, N.P., Venkateshwarlu, G. \& Vardia, H.K. (2012). Fatty acids composition of some selected Indian fishes. African Journal of Basic \& Applied Sciences4, 155160. doi: 10.5829/idosi.ajbas.2012.4.5.6627

10. Kaushik, S.J., Coves, D., Dutto, G. \& Blanc, D. (2004). Almost total replacement of fish meal by plant protein sources in the diet of a marine teleost, the European seabass, Dicentrarchus labrax. Aquaculture, 230(1-4), 391-404. doi: 10.1016/S00448486(03)00422-8

11. Mishra, K. \& Samantaray, K. (2004). Interacting effects of dietary lipid level and temperature on growth, body composition and fatty acid profile of rohu, Labeo rohita (Hamilton). Aquaculture Nutrition, 10(6),.359-369. doi: 10.1111/j.1365-2095.200 4.00311.x

12. Mohanty, B.P., Ganguly, S., Mahanty, A., Mitra, T., Patra, S., Karunakaran, D., Mathew, S., Chakraborty, K., Paul, B.N., Sarma, D. \& Dayal, S. (2019). Fish in human health and nutrition. Advances in fish Research, 7, 189-218.

13. Osman, H., Suriah, A.R. \& Law, E.C. (2001). Fatty acid composition and cholesterol content of select- 
ed marine fish in Malaysian waters. Food Chemistry, 73(1), 55-60.

14. Roques, S., Deborde, C., Richard, N., Skiba $\square$ Cassy, S., Moing, A., \& Fauconneau, B. (2020). Metabolomics and fish nutrition: a review in the context of sustainable feed development. Reviews in Aquaculture, 12(1), 261-282. doi: org/10.1111/ raq.12316

15. Sharma, P., Kumar, V., Sinha, A.K., Ranjan, J., Kithsiri, H.M.P. \& Venkateshwarlu, G. (2010). Comparative fatty acid profiles of wild and farmed tropi- cal freshwater fish rohu (Labeo rohita). Fish Physiology and Biochemistry, 36(3), 411-417. doi: 10.1007/ s10695-009-9309-7

16. Singh, K.K., Mridula, D., Rehal, J. \& Barnwal, P. (2011). Flaxseed: a potential source of food, feed and fiber. Critical Reviews in Food Science and Nutrition, 51(3), 210-222. doi: 10.1080/1040839090353724 1

17. Subasinghe, R., Soto, D. \& Jia, J. (2009). Global aquaculture and its role in sustainable development. Reviews in Aquaculture, 1(1), 2-9. doi: 10.1111/j.17 53-5131.2008.01002.x 